\title{
The Nature of Personal Identity in the Near-Death Experience: Paul Brunton and the Ancient Tradition
}

\author{
Kenneth Ring \\ Department of Psychology \\ University of Connecticut
}

\begin{abstract}
In this paper the nature of personal identity is examined from two perspectives: observations reported by selected near-death experiencers (NDErs) and the viewpoint represented by the late English writer Paul Brunton (1898-1981). NDEs suggest a continuation and enhancement of the sense of personal identity may give way in deeper experiences to an expanded and ecstatic state of union with the Light, in which one's individuality is nevertheless paradoxically preserved. Such experiences of the self are, according to Brunton, manifestations of the Overself, a central concept in Brunton's thought, which is next described and held to illumine many aspects of NDEs. The paper continues with an exploration of the implications of Brunton's understanding of NDEs for the issue of whether, and in what form, we may survive biological death and concludes by considering the relationship between the discoveries of contemporary near-death research and some of the teachings of the ancient mystery schools. It is argued that the writings of Paul Brunton constitute a rich source of materials for enlarging our grasp of the significance of the NDE.
\end{abstract}

Throughout the verbal traditions handed down by our earlier forefathers, and shining through the literature of the world, far back as the first rude manuscripts of Oriental peoples and up to the newest product of the printer's press of this year of grace, there has been a strange yet recurring allusion to another self within man. It does not matter what name was given to this mysterious self, whether it be called soul or breath, spirit or ghost. There is, indeed, no other doctrine in the world which possesses so farflung an intellectual ancestry as this.

- Paul Brunton The Secret Path (1935, p. 36)

A good case can be made that the most fundamental question in life is "Who am I?" At any rate, all self-inquiry must obviously begin 
with an exploration of this root query into the mystery of personal existence. For that reason, several of this century's greatest spiritual adepts and teachers such as Ramana Maharshi (1972), George I. Gurdjieff (Ouspensky, 1949; Bennett, 1974), and Roberto Assagioli (1971) have made the question central to their systems of selfrealization. Similarly, some of the world's most highly prized spiritual traditions - ranging from ancient Greek philosophy to contemporary Zen Buddhist practice - are grounded in the primacy of radical selfinquiry.

In this article, I would like to advance the proposition that modern research into the near-death experience (NDE) has furnished us with still another perspective that allows us to address this ultimate issue. Like mystics and sages, NDErs are persons who have come to their own understanding of this matter out of their own deep, inner experience; their conclusions are thus empirically based and are not the product of speculation or philosophical analysis. Not surprisingly, what emerges from their collective experience is a view that has many points of correspondence with ancient doctrines of the self.

In addition to drawing on the literature from the field of neardeath studies, however, I also intend to make use of the insights of a formerly well-known author and spiritual teacher whose once popular writings have since suffered from an unjustified neglect. Paul Brunton ${ }^{1}$ (1898 - 1981) was an English journalist and writer who traveled widely in the East and was recognized in his lifetime as a man of considerable spiritual attainment. In his writings, he, too, emphasized the necessity of self-inquiry, but more than that, Brunton in many ways anticipated nearly half a century ago most of the recent findings and conclusions of near-death research. He is, therefore, an especially timely writer despite the fact that his last book was published more than three decades ago. It is my hope that this paper may help to resurrect an interest in his valuable work.

Finally, after an exploration of the nature of personal identity from the standpoint of NDEs, buttressed by some of Brunton's own observations and concepts, I would like to consider the implications of my thesis for the question of whether, and in what form, we may survive biological death. In my conclusion, I will also touch on the relationship between the findings of contemporary neardeath research and the teachings of some of the mystery schools of antiquity.

I had risen into space, disentangled my soul from its mortal skein, separated 
myself into two twin parts, left the world which I had known so long. I experienced a sense of being etheralized, of intense lightness, in this duplicate body which I now inhabited. . . . My earthly body had really imprisoned me, the real "me," but now I was free. I had been borne hither and thither upon this planet by an organism which I had long confused with my real central self.

- Paul Brunton

A Search in Secret Egypt

(1936, pp. 74-75)

The first thing that will forcibly strike any student of the NDE when he or she focuses attention on the sense of personal identity during the NDE is how strongly most individuals retain that sense. NDErs will spontaneously exclaim - or will routinely aver when asked - that "it was me" or "I was myself" during their NDE. Typically, this persisting and undeniable impression of one's continuing personal identity at death is accompanied by feelings of surprised delight or even joy. Let me cite here just a few such illustrative examples from my own archival materials.

From a woman who nearly died of a cardiac arrest:

Respondent: Well, it was like, like I didn't have a body! But it was me. Not a body, but me. You know what I mean? Like I used to say to my father who didn't know me very well, that he should get to know the real me inside, instead of looking out here ... because that's what's important to me. It was me - inside.

Interviewer: The real you.

Respondent: The real me was up there; not this here [she points to her physical body].

From a man who was electrocuted:

The most important thing to realize ... was that I had never, ever lost me. I lost my body, but I didn't once lose me, because as I speak now is exactly the way I was at that moment. I was me! 'Cause I can remember looking around and saying, "Boy, what have you got yourself into now?" [laughs] The same laughter, my identity was still around me, so I am "me" inside of me.

Finally, from a woman who nearly died while giving birth:

The next thing I knew, I was in - I was standing in a Inist and I knew immediately that I had died and I was so happy that I had died but I was 
still alive. And I cannot tell you how I felt. I was, "Oh, God, I'm dead, but I'm here. I'm me!" And I started pouring out these enormous feelings of gratitude. . . My consciousness was filled with nothing but these feelings of gratitude because I still existed and yet I knew perfectly well that I had died. ...

But even more than this, the sense of continuing personal identity is often one in which the individual feels that he - the real he is greatly enhanced or has expanded capacities. In Life at Death (1980), I gave many examples of this quality of self-perception when I described how NDErs frequently spoke of markedly increased sensory-like acuities or hyperlucidity of understanding, and I have given additional and, I believe, even more impressive instances of it in my forthcoming book, Heading Toward Omega (in press). Since such observations are plentiful in my work and in the general literature of near-death studies, I will not quote additional cases here.

Obviously, just as the essential self, as perceived in NDEs, is often exalted, so the physical self is disdained. That is especially apparent during the out-of-body phases of the NDE when the physical body is commonly referred to in a detached, third-person mode. Just to cite one such instance here for many that could be used, consider this comment by a woman who was watching a medical team perform a tracheotomy on her:

Respondent: I can remember them working on me, but I was completely detached from it. I was very clinical. I mean, it was like, "They're hurting that girl." . . I kinda floated to the ceiling. I can name you what doctor was there. . . I said [to herself], "Oh, that girl is going to have a tracheotomy." It was "that girl," it was not me.

Interviewer: There was no connection between you and her?

Respondent: No.

Parenthetically, Brunton in describing an out-of-body experience $(\mathrm{OBE})$ of his own - when he felt close to death - was even more emphatic on this point:

I kept on looking at the recumbent relic which I had left behind. Somehow, it fascinated me. Was that discarded form the thing which, for so many years, I had considered as myself? I perceived then, with complete clarity, that it was nothing more than a mass of unintelligent, unconscious, fleshly matter (Brunton, 1936, p. 75) (italics added).

If we were to review the other features of the classical NDE - 
e.g., the passage through the tunnel, the confrontation with the light, the life review, the encounter with deceased loved ones, and so on we would of course find much additional evidence to support the notion that the NDEr typically maintains his sense of personal identity throughout the experience and is recognized by other beings in terms of his earthly identity and personal history. Since these facts will be familiar to most readers of this journal, I will merely note them here as relevant to my thesis.

Nevertheless, at this stage in our inquiry, we have only examined some of the typical aspects of one's sense of personal identity during an NDE. To develop my argument, however, we need to consider next the extent to which that sense of personal identity may expand in the deeper NDEs, in which it appears that the individual comes to a fuller realization of what his essential self actually is. That perspective will accordingly offer to the experiencer - and to us - a more complete answer to the primary question, "Who am I?"

To illustrate the depth of understanding, let me again refer to a couple of cases from my own archives.

First, here are the observations from a man who was clinically dead for several minutes as a result of a faulty operative procedure:

It was then that I experienced - experienced what we call a near-death experience. For me there was nothing "near" about it - it was there. It was a total immersion in light, brightness, warmth, peace, security. I did not have an out-of-body experience. I did not see my body or anyone about me. I just immediately went into this beautiful bright light. It's difficult to describe, verbally it cannot be expressed. It's something which becomes you and you become it. I could say, "I was peace, I was love." I was the brightness, it was part of me. ... You just know. You're allknowing - and everything is a part of you - it's just so beautiful. It was eternity. It's like I was always there, and I will always be there, and that my existence on earth was just a brief instant.

My second case is actually a continuation of the narrative I cited earlier from the woman who nearly died in delivery. The following passage came directly after her expressing her feelings of gratitude for continuing to exist and seems to represent a further progression of her experience and her understanding of it:

While I was pouring out these feelings ... the mist started being infiltrated with enormous light and the light just got brighter and brighter and brighter and, as everybody says, it was so bright but it doesn't hurt your eyes, but it's brighter than anything you've ever experienced in your whole 
life. At that point, I had no consciousness any more of having a body. It was just pure consciousness. And this enormously bright light seemed almost to cradle me. I just seemed to exist in it and be part of it and be nurtured by it and the feeling just became more and more and more ecstatic and glorious and perfect. And everything about it was - it just didn't bear any relationship to anything! The feeling - if you took the one thousand best things that ever happened to you in your life and multiplied by a million, maybe you could get close to this feeling, I don't know. But you're just engulfed by it and you begin to know a lot of things. I remember I knew that everything, everywhere in the universe was OK, that the plan was perfect. . . And the whole time I was in this state, it seemed infinite. It was timeless. I was just an infinite being in perfection.

Clearly, these persons have during their NDEs become aware of much more than their usual identity. They become united with and absorbed into a seemingly universal, formless perfection that engulfs them in what can only be called pure love. Their sense of being likewise appears to expand to infinity, and they come to feel that what they are experiencing is eternity itself. Yet it also seems that throughout this tremendous expansion of their being, they have not lost themselves; it's rather more as though they have discovered that there is no limit to their essence and that it necessarily goes far beyond that with which they were previously consciously identified.

I will need to postpone until the next section my interpretation of the significance of this kind of experience, although the general conclusion toward which it points may already be obvious. Right now, however, I want to bring this section to a close by citing one last case of an NDE, one that is unique in my files and that affords the most complete understanding of the entire question of personal identity as disclosed by the study of NDEs.

In view of the importance of the case to the argument I wish to develop, I need to give just a bit of background here. The experience quoted below comes from a thirty-year-old woman I met in Boston in February, 1983, on the occasion of a lecture I was giving on NDEs. During an intermission, we talked briefly, and, several weeks afterward, she sent me a fourteen-page typewritten account of her NDE. Her narrative disclosed that her NDE had come about early in 1979 after several months of being bedridden from an undiagnosed illness that she contracted while living in Central America. Her NDE itself took place while she was being driven to a local first-aid station twenty miles from where she and a companion were living. Because of the value of her testimony for what is to come, I need to quote at length from her account. As you will quickly note, her NDE began not with the usual feelings of ecstatic liberation from the body 
but with quite the opposite - the terror of ego-death.

As she felt herself slipping closer to death, J.T. was aware of her various sensory systems shutting down: first her vision ceased, then her hearing, and, finally, her sense of touch. Yet throughout this period, J.T. wrote, she was "somehow" able to see and hear, but not in the "usual way." Concurrent with these events, however:

A snowballing effect occurred. As all of my energy started rolling inward, I was frantic. It was living hell and I never experienced such terror in my life.

It was the death of my ego. It was accompanied by an incredible and totally consuming terror. Also, great struggle and upheavals were involved in the passing away of my ego.

So what is the ego? You could say it is the small $i$ (the self of the SELF), the desire body, personal habits and patterns of the personality that comprised the J.T. of the twentieth century, a strong tendency to cling to things, a way of perceiving and dealing with the world, whatever. My ego was strong and formidable but no match for gentle death.

It may seem odd to you (as it was to me) that one part of me could watch detached, surprised and interested in the total pattern of things, while another sector went screaming (and I do mean howling) and wailing away. Most of my memories of this juncture are taken up with my struggle and terror. The image I retain is the simile of a small child being dragged somewhere against his will and kicking and screaming the whole way....

There came a point where I realized I "was dead," irrevocably dead, but there was still someone "home." It wasn't the annihilation I had thought it would be [J.T. was an agnostic at the time and expected "total annihilation"]. Someone was watching all this and that someone was still me, and yet the me, as I was accustomed to think of me, was dead. The me (SELF) was watching it all and had witnessed the death of ane (ego). It was all very confusing and yet very clear at the same time.

Concurrent with this realization, I surrendered to the force and powers that be, I gave up and "said" in effect, "OK, I give up, I'll go quietly and peacefully." I was aware of something else, a larger sense of $I$ or of another presence....

I felt a loving presence surrounding me and in me. The space was composed of that presence of love and peace, yet nothing was there at all. All potentiality was there and complete, but not actualized. The best words are "All That Is" was there and yet "Nothing" was there too. It was a lovely place to be; very peaceful, total harmony, everything was there and nothing was there, but I was there witnessing (or being) the "ALL" and "Nothing" of that "Place."

I experienced what I call a judgment; a total review of my life. It was experienced in its essence and totality. It was surveyed in one clump, as it were. You could say the creator judged me, and be correct. I felt it was that, but even more, it was the totality of my Self; my larger SELF, my True Self, judging my little self, the ego, the habits and patterns or tendencies of J.T. within the context of the twentieth century.

I was ashamed and dismayed at what I'd found. I was judged and found 
myself wanting, badly wanting. If I'd been a teacher I'd have given myself an $\mathrm{F}$.

My life for the first twenty-five years wasn't so bad. I was average, didn't do anything drastic, did pretty much the usual things people do and what was expected of me. But I lived entirely for the gratification of the little self, the ego. The potentiality which existed within me had not been developed in the most beneficial direction -- in short, I was selfish as hell. I had used all that was at my disposal for my personal small egoself, and not for larger mankind.

It was then communicated to me that the aim in my life was to bring the Love that Jesus, Buddha, Ramana Maharshi, etc., spoke of, into actuality in my life. To strive for it, to experience it to the best of my ability. That was to be shared - the knowledge and the Love that was gathered - with the peoples of the world.

I was then asked if I wanted to continue on my present course of action or to return to life on earth. I very much wanted to continue life in the world as I knew it and take up the challenge. To learn to use my potentiality for other than small self-ego related gain....

Shortly after making the decision to return, J.T. found herself becoming aware again of physical energies and of receiving oxygen from a physician. She was back to what we here call reality.

From J.T.'s account, then, we can begin to see the strands of thought that weave together to form our sense of personal identity and how an NDE may have the potential to unravel those strands from ourselves and, though the separation may be wrenching indeed, thereby to disclose the luminous form of ourselves, the silent omniscient witness that Brunton has called the Overself.

The Overself is the true being, the divine inhabitant of this body, the Silent Witness within the breast of man. Man lives every moment in the presence of this divine self, but the membrane of ignorance hangs over him and covers sight and sense.

- Paul Brunton

The Secret Path

(1935, p. 97)

Except, of course, at death. It is when sight and sense fail - as they failed for J.T. during her NDE - that the membrane of ignorance may be pierced and the bright ray of self-knowledge is able to blaze forth to illuminate our consciousness. It is in that moment, then, that we may come to a realization of who and what we truly are. Death punctures a hole in the tight fabric of the ego, which allows 
us to slip through in a moment outside of time to experience ourselves as infinite perfection. When that happens we realize in the depths of our own being the truth of Meister Eckhart's dictum that "God is at the center of man." It is direct contact with the Overself that enables us to have this consummate knowledge, and it is for that reason that the revered sages of all epochs have stressed the importance of dying to the ego before the death of the body supervenes.

In these days when, because of modern resuscitation techniques, millions of people are undergoing NDEs, the direct knowledge of the Overself is being vouchsafed to unprecedented numbers of individuals who come to the experience completely unprepared for and unable to grasp the enormity of the truth that is disclosed to them. As with psychedelic usage in the sixties, the scope and depth of NDE-induced revelations may be more than most people can filter through their preexisting frameworks.

This is where a writer like Brunton can prove to be of immense value for those who seek a deeper understanding of the NDE. Indeed, in this respect, Brunton appears to be something of a modern hierophant to those who have nearly died as a result of their involuntary initiation through the portals of clinical death. And central to Brunton's thought - and to the NDE itself - was his concept of Overself. Let us see how Brunton - a master wordsmith if ever there was one - explicated it.

In The Secret Path (1935), one of Brunton's most accessible books and a good, if brief, introduction to his basic ideas, he offered this general overview:

The whole matter might perhaps be put more plainly by saying that the human race, in the course of its long history, has superimposed a second self upon the individual nature with which each man began. This second self is usually called the person and came into being through a union of spirit and matter, through a commingling of particles of consciousness drawn from the ever-conscious real self with particles of unconscious matter drawn from the body. This second and later self is the one we each of us know, the personal self, but the first and real self, which existed before thinking and desiring appeared within the beginning of man, is the one which few of us know, which is subtle and not so apparent because it makes us all partake of the nature of divinity. It lives always over our heads, an angelic thing of unimaginable grandeur and mysterious sublimity, and therefore I call it the Overself (Brunton, 1935, p. 42).

The Overself, then, is our higher self or soul, and, according to Brunton, it is "man's essential being, the all-important residue which is left when he succeeds in banishing the thought of his identification 
with the physical body and the intellect" (Brunton, 1938, pp. 251-252). That statement helps us understand why the Overself tends to suffuse our consciousness at death as the onset of death serves to weaken our attachment to both body and intellect.

There is a paradox here, however, because although the Overself is our higher self, there is only one Overself, "one universal divine self resting in all men" (Brunton, 1938, p. 252). Brunton said that the divine Overself always is in its essence the same in all individuals, but that it has a unique relationship with each human being.

As for the qualities of the Overself, Brunton wrote that the Overself is eternal; with respect to our lives, it is also omniscient, yet in its role as "the hidden observer" of the ego, it is impartial and detached. As for our knowledge of $i t$ :

We do not "see" the Overself; we apprehend it. Visions merely disclose its finest garments, its robes of dazzling light, albeit they are but robes.

We do not behold its beauty; our being dissolves into its breath and we become that which poet, painter, sculptor, musician seek but scarcely find.

The Overself is the supreme reality, but its reality is too subtle, too exquisite, too rare, for audible expression (Brunton, 1938, p. 252).

In short:

From the human standpoint, the Overself is the deeper layer of mind where man can become conscious of God. It is the timeless spaceless immanence of the universal being in a particular center (Brunton, 1943, p. 196).

This mystical meeting-point, the Overself, represents the utmost extent to which the finite self can consciously share in the ultimate existence. It is that fragment of God which dwells in and yet environs man, a fragment which has all the quality and grandeur of God but not all the amplitude and power of God (Brunton, 1943, p. 193).

Needless to say, Brunton spent many pages in his various books trying to help his readers gain an appreciation of the Overself, and the snatches I've culled from his writings to present here cannot possibly convey the sense of his compelling exegetic commentary on the subject. Still, I hope these bare outlines are sufficient to enable you to intuit the connection I wish to make between the essence of the NDE and Brunton's concept of the Overself. In any case, I must now return to the issue I raised at the outset of this paper: what answer does the NDE give to the question, "Who am I?"

It is here of course where Brunton's deep probings of the self will 
prove to be most illuminating and where his direct knowledge of NDEs - forty years before the work of Kubler-Ross and Moody can bridge the gaps we need to cross. It is here also that Brunton's concepts will be found to dovetail perfectly with J.T.'s experience and the conclusions of our inquiry fall into place.

In several of his books Brunton showed that he had a clear understanding - at least judged by the findings of modern near-death studies - of just what happens at death. The description of the transition into death he gave in his book The Wisdom of the Overself (1943, p. 152-157), for example, could easily serve as a good summary of most of the major features of the NDE. In Brunton's case, of course, his interpretation of the passage into death was couched in terms of an encounter with the Overself. To illustrate Brunton's approach to the NDE, let me quote just one portion of his description, specifically concerned with the life-review phase of the experience. Before proceeding to these remarks of Brunton, however, you may wish to reread the last part of J.T.'s account, where she spoke of the judgment, in order to appreciate just how astute was Brunton's grasp of the NDE.

What happens next is that a living being, which although he does not know it has already imperturbably observed the death of his bodily being, a hidden "I" which has always observed the surface "I," something within him yet something that he has not hitherto recognized as himself, will now touch his consciousness. This being is none other than his own majestic Overself. Through its eyes he will gaze afresh at the total impression rather than the episodal detail of his early life. Through its revelatory eyes he becomes his own incorruptible judge. The purely selfish, personal point of view suddenly deserts him. For the first time, perhaps, he sees himself not only as others see him but also as the impersonal power of karma sees him. During this time he comes face to face with the consequences for other persons of his acts whilst on earth, consequences of which he was often quite unaware or in which he was often egotistically uninterested. He then perceives that many of his own misfortunes - so vividly depicted again in this amazing panorama - were definitely self-made and self-earned. By this diviner light of a conscience magnified one thousand-fold, he feels that whatever happened to him was a just result, was traceable in the end to his own character and his own deeds. A great remorse overwhelms him. He puts passion aside and sees this surface "I" as the once-hidden observer sees it, without its own self-flattery and unconscious self-deception. . . . Finally, he is made to ask himself the question, What have I done with this gift of life? (Brunton, 1943, pp. 155-156) (italics in original)

Thus, for Brunton, the sense of a divine presence, the brilliant, radiant light, the pure love, the total knowledge, and the feeling of 
ultimate perfection - in short, the common features of deep NDEs - are all to be understood as emanations or expressions of the Overself, "that fragment of God," as Brunton called it, that discloses to us finally and forever just who we are. The answer to that question, of course, is not one that can be put into words - "the Overself is the supreme reality, but its reality is too subtle, too exquisite, too rare, for audible expression" (Brunton, 1938, p. 252) - it is a state of being. And it is a state that many NDErs know from their direct experience, though they, too, must remain mute in order to be most faithful to it.

Other qualities of NDEs - such as heightened powers of perception and cognition - are also readily understood within Brunton's framework. For example, he spoke of the "clairvoyant vision" that comes with death while the emergence of the Overself into consciousness infuses thought with a razor-sharp objectivity and clarity.

Though few NDErs could be expected to be familiar with Brunton's thought at the time of their experience, many of them, I suspect, would come back from it with at least a dim intuitive appreciation for his viewpoint. In support of that assertion, let me refer here to some recent findings of my own that will be described in Heading Toward Omega (in press).

In that research, I asked a small subsample of NDErs - slightly fewer than thirty in all - to complete some questionnaires for me. One of these questionnaires asked respondents to rate a series of concepts in terms of their belief/disbelief in them using a five-point scale that ranged from +2 to -2 . One of the concepts to be rated was "God." After their experience, everyone in my sample - without exception - gave the maximum positive rating $(+2)$ to describe their belief in God. Interestingly enough, only 40 percent of my sample, which was quite diverse in terms of pre-NDE religious orientation and affiliation, had felt as strongly on this matter before their NDE, but everyone else shifted to the maximum extent possible afterward. Behavioral scientists will know how rare it is, even with a small sample, to have absolute uniformity of response to a Likert-type questionnaire item. That uniformity, of course, bolsters my contention that NDErs, regardless of their prior religious beliefs, understand and acknowledge that their experience has opened them up to the divine light within themselves that Brunton called the Overself.

This is the state of death. Now I know that I am a soul, that I can exist 
apart from the body. I shall always believe that, for I have proved it... . I had proved survival in what I thought the most satisfactory way - by actually dying and then surviving!

- Paul Brunton

A Search in Secret Egypt

(1936, p. 75)

Paul Brunton's exultant cry of his liberation from death is of course now the common testimony of countless NDErs who have made the same temporary crossing that Brunton did fifty years ago. Certainly one of the most reliable findings of near-death research is that NDErs, following their experience, tend to show a dramatic increase in their conviction that there is indeed a life after death and that they have glimpsed its beginnings. From their collective perspective, then, NDErs seem to be affirming not only that we retain our personal identity at death but that we carry that identity with us into the realms beyond death.

While that may be so, Brunton's own analysis gives us cause to wonder whether the common wisdom of NDErs is necessarily the last word on the subject. Because Brunton's understanding of the transition into death was, by modern standards, so knowledgeable, it may behoove us to consider carefully his claims for what happens to us after death.

Brunton's argument was predicated on a distinction he made between what we may call "egoic survival" and what Brunton labeled "spiritual immortality" (Brunton, 1938, p. 41). The distinction between these concepts is that whereas the former perpetuates the ego, the latter dissolves it. To appreciate the importance of the distinction, however, it will be necessary to consider Brunton's view on the nature of the ego itself.

For Brunton the personal ego was, at bottom, a thought, albeit a complex one. In no sense is it, however, anything fixed or definite. Brunton was very clear on the point and uncompromising in his discussion of what it means for the possibility of egoic survival:

The personal "I" is but a bundle of impermanent hopes and transient fears, a little sheaf of cravings that change with the changing years. Nothing that we know among them is immortal even during this present earthlife; how then can they be immortal through all eternity? To cultivate a belief in a personal ego that will permanently survive in a state of fixation is to prolong the illusion that even now blinds our eyes to the truth ... (Brunton, 1943, p. 190). 
Brunton's characterization of the personal ego here may seem familiar, and indeed it is, for once again his remarks recall the experience of J.T. as she described the breaking down of her ego - her "desire body," as she called it - during the onset of her NDE. As that process was unfolding for her, her ego was dissolving. How, then, could it possibly survive death?

The mere fact that a person appears abruptly in time makes him inescapably mortal. For whatever has a beginning must have an ending. This is an inexorable law of Nature. Yet, the notion of the eternal existence of the same person in a world which is itself subject to eternal change, a notion which constitutes the orthodox concept of immortality, is one of the fond delusions which man has always liked to harbor (Brunton, 1943, p. 191).

Of course, we can continue to cling to that bundle of thoughts that constitute the "I" and carry that transient identification tag across the threshold into death for whatever fate may await us, but, for Brunton, that is to continue to perpetuate the illusion of the ego and to settle for what he disdained as "mere survival" instead of reaching out for true deathlessness. Thus "egoic survival" in Brunton's view is actually a failure to achieve the highest prize that death affords, which is spiritual immortality.

Nevertheless, Brunton was able to see potential value in our common craving for and belief in personal survival, but only if one can penetrate to the core of that tendency:

Even in this widespread longing for personal continuance we can detect the beginnings of what will one day grow into the nobler longing to live forever in the true immortality. For it is an unconscious perception that human existence does possess something within it which is unaffected by events in time and is therefore genuinely eternal, something which stands apart from all the miserable mutations of the flesh and the "I." It is indeed an unformulated intuition which, hiding among the perishable elements of personality, affirms that there is an imperishable principle which cannot be brought to an end with the end of the body. The popular error which transfers what is known, namely the characteristics of the physical body, to what it does not know, namely, the mind for which that body is but a cluster of ideas, must be corrected. When this is done the desire for the endless continuance of a body-based "I" naturally sinks to a secondary place. ... This view of immortality as belonging to the higher individuality of Overself rather than to the lower personality will then replace the former one... (Brunton, 1943, p. 192).

Thus, Brunton took his stand with many of the world's great adepts, stretching back to Plato and undoubtedly beyond, in chal- 
lenging us to transcend the widespread assumption that a life after death necessarily means a personal existence of some kind. If one follows his advice and thought, it is possible to see that in fact eternity - as a state of being - is actually available to us at this moment and has nothing at all to do with death. It is only that the moment of death itself is one of life's supreme opportunities to realize the truth about one's real identity. But that truth is accessible whenever, before physical death, we find the avenue that leads to the Overself. In this connection, we may do well to remember the famous exclamation of Richard Maurice Bucke, the author of the classic book Cosmic Consciousness (1901/1969), who, in describing his own experience, said:

I became conscious in myself of eternal life. It was not a conviction that I would have eternal life, but a consciousness that I possessed eternal life then ... (James, 1958, p. 307).

In asking us to ponder these issues, Brunton was really exhorting us to discover for ourselves the Overself now, before death comes, rather than glibly assuming that death itself will automatically reveal the truth about existence to us. After all, he cautioned, "even those who fondly believe and ardently hope for . . . personal survival . . . will even there have one day to wake up and start in quest of the Overself" (Brunton, 1943, p. 191).

Scientific, psychical and psychological research is changing the Western world's attitude towards matters which were once dismissed as fanciful nonsense. Such research is lifting the ideas of the ancients out of the undeserved contempt in which they have lain while younger notions sprang to lusty manhood. . . . Our best scientists and foremost thinkers are joining the ranks of those who believe there is a psychic basis to life. What they think today, the masses will think tomorrow. We have begun and perhaps rightly - as complete skeptics; we shall end as complete believers: such is my positive prediction. We shall rescue belief in the soul from the cold air of modern doubt. The first great message of the ancient Mysteries - "There is no death," although always susceptible of personal experiential proof by a mere few, is destined to be broadcast to the whole world. 
Brunton himself was a deep student of the ancient Mysteries, especially those of Egypt, and wrote at length about them in one of his earlier books, A Search in Secret Egypt (1936). Here again, however, Brunton reveals his contemporaneity, for he was able to see into the connection between these fabled secret initiation rites and what they had to tell the modern world about death. That relationship is summed up in a line from the biographer Plutarch which Brunton quoted in at least two of his books - who said following his own initiation experience: "At the moment of death the soul experiences the same impressions as those who are initiated into the great Mysteries." Thus, according to Brunton, those candidates who successfully passed through their initiation in the temples dedicated to Osiris would be enabled to know experientially the truth of the great secret: "there is no death."

Through his own painstaking research, travel, and personal experience (including a memorable overnight stay inside the Great Pyramid at Giza), Brunton was able to formulate his own reconstruction of the aim of those mystery rites and of the techniques the Egyptian hierophants used with those undergoing the most advanced form of initiation:

That august rite was nothing more or less than a process which combined hypnotic, magical and spiritual forces in an attempt to detach the candidate's soul from the heavy bondage of his fleshly body for a few hours, and sometimes for a few days, that he might ever after live with the memory of this epoch-making experience. ... In this marvellous experience the finite mind of man was drawn into contact with the infinite mind of his superior divinity. He was able for a brief while to enter into silent, spellbound communion with the Father of All, and this fleeting contact of incomparable ecstasy was enough to change his entire attitude towards life. He had partaken of the holiest food that exists in life. He had discovered the ineffable ray of Deity which was his true innermost self, and of which the soul-body which survives death was merely the intangible vesture. He was, in verity and fact, born again in the highest sense. . . .

Only in such a state was it possible for a man to perceive the spiritworld as it was perceived by the spirits themselves, to see visions of the gods and angels, to be taken through infinite space, to know his innermost self and, ultimately, to know the true God.... The doctrine of the immortality of the soul was more than a mere doctrine now; it was a proved fact, which had been completely demonstrated to him.... He no longer believed in death, he believed only in Life - eternal, self-existent, ever-conscious Life....

Such was the instruction received in the Mysteries, an institution so celebrated in antiquity, so distegarded in modernity (Brunton, 1936, pp. 184-189). 
Brunton's reconstruction of the form and purpose of these initiations agrees in its broad outlines with those of other noted students of these mysteries (e.g., Schuré, 1971; Grosso, 1983), and Brunton also concurs with Grosso's (1983) contention that the Eleusinian mysteries of ancient Greece had a similar structure and intent. Indeed, Brunton himself argued that such mystery rites were extremely widespread in the pre-Christian world and even extended into the Western hemisphere.

The contemporary relevance of all this is, however, what I wish to emphasize here. The modern world is witnessing the emergence of a new mystery school where resuscitation techniques administered by physicians have replaced hypnotic procedures practiced by high priests. The initiates of course are those who have suffered clinical death, and the initiation itself is the NDE. In the far-off days of which Brunton wrote, the candidates were few and carefully chosen; these days they number in the millions and come involuntarily. Yet what is learned by the survivors of both the ancient and modern forms of these initiations is, if we can trust Brunton, identical. We are ensouled selves, facets of divinity, and our true being does not merely survive death but is immortal.

Why it is that this ancient wisdom has to be impressed so directly on so many at this time in our planet's sorrowful history is for each of us to ponder. Unfortunately since we live during a period of many initiates but few hierophants, each of us must search out the answers as best we can, finding our sources of guidance where we may. For my part, I have found Brunton's writing helpful in providing a framework for understanding the deeper significance of NDEs.

In any case, it appears that his prophecy of nearly half a century ago is indeed coming true: the world, thanks in part to modern scientific research, does seem to be growing increasingly aware that "there is no death." Paul Brunton would not be surprised by those developments, for during an earlier dark period in world affairs, he wrote:

History moves in cycles, that which has been shall be again; gloom and chaos are once more upon us, while the innate urge of man to re-establish communication with the higher worlds troubles him anew. Wherefore it is the writer's hope that conditions may be found, circumstances may be propitious, and the right persons forthcoming to plant a modern version, entirely altered to suit our changed epoch, of those Mysteries once more in each of the five continents of our world (Brunton, 1936, pp. 193-194). 


\section{NOTE}

1. I am very much indebted to Mineda J. McCleave for drawing my attention to the relevance of Brunton's writings for near-death research and for making a number of his formerly hard-to-obtain books available to me. Happily, Samuel Weiser is currently reissuing almost all of Brunton's books in attractive cloth-bound editions.

\section{REFERENCES}

Assagioli, R. Psychosynthesis. New York: Viking, 1971.

Bennett, J.G. A Spiritual Psychology (Rev. Ed). Lakemont, GA: CSA Press, 1974.

Brunton, P. The Secret Path. New York: E.P. Dutton, 1935.

Brunton, P. A Search in Secret Egypt. E.P. Dutton, 1936.

Brunton, P. The Quest of the Overself. E.P. Dutton, 1938.

Brunton, P. The Wisdom of the Overself. E.P. Dutton, 1943.

Bucke, R.M. Cosmic Consciousness. E.P. Dutton, 1969. (Originally published 1901).

Grosso, M. Jung, parapsychology, and the near-death experience: toward a transpersonal paradigm. Anabiosis, 1983, 3, 3-38.

James, W. The Varieties of Religious Experience. New York: Mentor, 1958.

Maharshi, R. The Spiritual Teachings of Ramana Maharshi. Berkeley, CA: Shambala, 1972.

Ouspensky, P.D. In Search of the Miraculous. New York: Harcourt, Brace and World, 1949.

Ring, K. Life at Death. New York: Coward, McCann and Geoghegan, 1980.

Ring, K. Heading Toward Omega. New York: Morrow, in press. Schuré, E. The Mysteries of Ancient Egypt. Blauvelt, NY: Rudolf Steiner Publications, 1971.

Requests for reprints to:

Kenneth Ring

Department of Psychology

University of Connecticut

Storrs, CT 06268 